\title{
An international survey of nutrition practices in adult patients receiving veno-venous ECMO
}

\author{
DE Bear ${ }^{1,2^{*}}$, J Haslam² ${ }^{2}$ L Camporota ${ }^{2}$, M Shankar-Hari ${ }^{2}$, NA Barrett $^{2}$ \\ From ESICM LIVES 2015 \\ Berlin, Germany. 3-7 October 2015
}

\section{Introduction}

The use of veno-venous Extra-corporeal Membrane Oxygenation (vv-ECMO) in adults with severe respiratory failure is increasing. Nutrition whilst on vv-ECMO is challenging as inadequate feeding, mainly due to gastric intolerance is common [1-4]. Our understanding of how to meet nutrient needs in this high-risk patient is limited.

\section{Objectives}

To improve our understanding of the nutritional support preferences and practices by conducting an international survey of adult ECMO centres.

\section{Methods}

Details for International ECMO centres were obtained from our database used in previous surveys. Survey questions were developed through an iterative process and assessed for content and face validity. None of the survey domains were mandatory. This resulting 38-question online survey was emailed to 161 eligible ECMO centres using Smart Survey ${ }^{\circledR}$ (Smartline International Ltd, Gloucestershire, UK). Sole paediatric centres were excluded. The need for informed consent was waived by the local research and ethics committee.

\section{Results}

Sixty-seven (42\%) eligible centres responded to the survey. One third of centres managed less than $10 \mathrm{vv}$ ECMO patients over the previous year.

\section{Estimating nutritional requirements}

The most common equation to determine energy requirements is $20-25 \mathrm{kcal} / \mathrm{kg} /$ day $(17 / 34 ; 50 \%)$ and $1.5 \mathrm{~g} / \mathrm{kg} /$ day for protein (11/32; 34\%).

'Guy's and St Thomas' NHS Foundation Trust, Department of Nutrition and Dietetics, London, United Kingdom

Full list of author information is available at the end of the article

\section{Route of initial feeding}

Out of 37 responses, 29 (78\%) use naso-gastic feeding as the initial route of feeding. Five commence parenteral nutrition first (14\%) and 3 (8\%) post-pyloric feeding.

\section{Early enteral feeding}

Twenty two out of thirty six respondents (61\%) report feeding within 24 hours of commencing vv-ECMO. Twelve centres (33\%) feed within 48 hours and one (3\%) within 72 hours. One centre (3\%) reports never feeding their vv-ECMO patients.

\section{Gastro-intestinal intolerance}

Gastro-intestinal intolerance is perceived as common in these patients with 16 out of 26 respondents (69\%) reporting that $50 \%$ or more of their patients require prokinetics drugs during their vv-ECMO run.

\section{Conclusions}

The survey identifies significant heterogeneity in assessment and provision of nutritional requirement in these patients. Lack of evidence coupled with lack of guidelines relating to nutritional support explains this heterogeneity. Our survey highlights an urgent need for focused research in this area.

\footnotetext{
Authors' details

'Guy's and St Thomas' NHS Foundation Trust, Department of Nutrition and Dietetics, London, United Kingdom. 'uy's and St Thomas' NHS Foundation Trust, Department of Critical Care, London, United Kingdom.

Published: 1 October 2015

\section{References}

1. Scott $L K$, et al: Early enteral feedings in adults receiving venovenous ECMO. JPEN 2004, 28(5):295-300.

2. Lukas $G$, et al: Nutritional support in adult patients receiving extracorporeal membrane oxygenation. Crit Care Resusc 2010, 12(4):230-243.
}

(c) 2015 Bear et al.; This is an Open Access article distributed under the terms of the Creative Commons Attribution License (http:// creativecommons.org/licenses/by/4.0), which permits unrestricted use, distribution, and reproduction in any medium, provided the original work is properly cited. 
3. Ferrie $S$, et al: Nutrition support during extracorporeal oxygenation (ECMO) in adults: a retrospective audit of 86 patients. ICM 2013, 39:1989-1994.

4. Bear $\mathrm{DE}$, et al: Jejunal feeding associated with improved nutrient delivery compared with gastric feeding in patients receiving extracorporeal membrane oxygenation. ICM 2011, , Suppl 1: S294, Sept.

doi:10.1186/2197-425X-3-S1-A295

Cite this article as: Bear et al: An international survey of nutrition practices in adult patients receiving veno-venous ECMO. Intensive Care Medicine Experimental 2015 3(Suppl 1):A295.

\section{Submit your manuscript to a SpringerOpen ${ }^{\circ}$ journal and benefit from:}

- Convenient online submission

- Rigorous peer review

- Immediate publication on acceptance

- Open access: articles freely available online

- High visibility within the field

- Retaining the copyright to your article

Submit your next manuscript at $\gg$ springeropen.com 